\title{
Two-Year Follow up on the Protective Value of Dust Masks against Farmer's Lung Disease
}

\author{
Hirotaka KusaKa, Hideki Ogasawara*, Mitsuru Munakata, Kazunori Tanimura, Hideaki Ukita, \\ Naomi Denzumi, Yukihiko Homma** and Yoshikazu KawaKami
}

\begin{abstract}
Some advocate moving away from the farm environment for farmers affected with farmer's lung disease (FLD), but most affected farmers still live on farms. In this study, we evaluated the practicality of dust masks and their effectiveness in prevention of FLD. The dust masks we chose were practically used and no new severe episodes of FLD developed in 20 of 21 farmers with FLD using the masks during a 2-year period. When the farmers took off the dust masks in a farming environmental provocation test, statistically significant reductions in FVC (mean 3.43 to 3.35 $\mathrm{I}, \mathrm{p}<0.01$ ), $\mathrm{D}_{\mathrm{L}}$ co (mean 19.6 to $18.2 \mathrm{ml} /$ torr $/ \mathrm{min}, \mathrm{p}<0.01$ ), and $\mathrm{D}_{\mathrm{L}} / \mathrm{V}_{\mathrm{A}}$ (mean 5.1 to 4.8 $\left(\times 10^{-3}\right) 1 /$ torr $\left./ \mathrm{min}, \mathrm{p}<0.01\right)$ were observed several hours after exposure. These findings suggest that the dust masks were used practically during routine dairy farming and were effective in protection against FLD.
\end{abstract}

(Internal Medicine 32: 106-111, 1993)

Key words: provocation test, hypersensitivity pneumonitis

\section{Introduction}

Farmer's lung disease (FLD) is self-limiting if exposure to the offending antigens ceases, but continuous reexposure or numerous subacute episodes of hypersensitivity pneumonitis can lead to interstitial fibrosis. Therefore, removal of patients from the farm environment is recommended (1-4). We have been doing a field survey on FLD in the farming community Horonobe-cho, in the northern part of Hokkaido, Japan, since $1974(5,6)$. During this survey, we have been instructing some of the farmers with FLD who have pulmonary fibrosis possibly due to FLD, to stop farming or handling hay. However, this attempt has not been successful, mainly for financial reasons. Most farmers with a past history of FLD seem to be willing to take appropriate precautions under circumstances when exposure might occur. Use of a dust mask is one preventive measure which does not require stopping farming. If a farmer with a past history of FLD must continue periodically to handle moldy hay, a dust mask may diminish or prevent recurrent attacks of the disease. Some types of dust masks may be hot, difficult to breathe through, and ineffective, resulting in poor farmer compliance. However, during routine dairy farming work, the practical use and effectiveness of dust masks as a preventive measure have not been fully studied. In this study, we evaluated the practicality of dust masks and its effectiveness in prevention of FLD. Twenty-one farmers with a past history of FLD were supplied with dust masks and instructed to wear them for 2 years. The following studies were done: (1) Investigation of the incidence of acute episodes of FLD before and while wearing the mask, and (2) a one-day environmental exposure trial. Symptoms, physical examinations, chest roentgenograms, and pulmonary functions were examined.

\section{Subjects}

Twenty-eight cases of FLD were detected in the northern part of Hokkaido from 1974 to 1984. Diagnosis was based on a combination of factors, including known exposure, typical clinical examinations, chest roentgenograms, pulmonary function tests, serum precipitins, and transbronchial lung biopsy (in 2 cases). We asked 25 out of the 28 farmers with FLD to participate in this study. The other 3 farmers were excluded from our study because they had already contracted lung fibrosis, or the active stage of FLD. Informed consent was obtained in

From the First Department of Medicine, School of Medicine, Hokkaido University, Sapporo, *the Department of Medicine, Asahikawa Municipal Hospital, Asahikawa and **the Department of Medicine, Medical Center, Hokkaido University, Sapporo

Received for publication July 30, 1992; Accepted for publication January 7, 1993

Reprint requests should be addressed to Dr. Hirotaka Kusaka, the Department of Medicine, Sunagawa City Medical Center, W-4, N-2, Sunagawa 073-01, Japan 
Protective Value of Masks against FLD

Table 1. Subjects $(\mathrm{n}=21)$

\begin{tabular}{|c|c|c|c|c|c|c|}
\hline Case & Age & Sex & $\begin{array}{l}\text { Years on } \\
\text { farm }\end{array}$ & $\begin{array}{l}\text { Hours in } \\
\text { barn }\end{array}$ & $\begin{array}{c}\text { Hay hand- } \\
\text { ling time (min) }\end{array}$ & Smoking \\
\hline 1 & 55 & $\mathrm{~F}$ & 32 & 5.0 & 40 & No \\
\hline 2 & 59 & $\mathrm{~F}$ & 30 & 0.0 & 0 & No \\
\hline 3 & 59 & M & 27 & 6.0 & 0 & No \\
\hline 4 & 76 & M & 40 & 5.0 & 90 & No \\
\hline 5 & 53 & M & 20 & 3.0 & 40 & No \\
\hline 6 & 68 & M & 45 & 3.5 & 5 & Current \\
\hline 7 & 53 & $\mathrm{~F}$ & 38 & 3.0 & 0 & No \\
\hline 8 & 63 & $\mathrm{M}$ & 50 & 1.5 & 20 & Current \\
\hline 9 & 42 & $\mathrm{~F}$ & 20 & 4.0 & 60 & No \\
\hline 10 & 44 & M & 23 & 3.0 & 15 & Current \\
\hline 11 & 54 & $\mathrm{~F}$ & 35 & 4.0 & 10 & No \\
\hline 12 & 50 & $\mathrm{~F}$ & 39 & 3.0 & 0 & No \\
\hline 13 & 48 & M & 20 & 4.0 & 60 & No \\
\hline 14 & 49 & M & 25 & 2.5 & 30 & Current \\
\hline 15 & 39 & M & 7 & 6.0 & 10 & No \\
\hline 16 & 58 & M & 17 & 6.0 & 0 & Current \\
\hline 17 & 52 & $\mathbf{F}$ & 31 & 5.0 & 0 & No \\
\hline 18 & 57 & M & 42 & 5.0 & 20 & No \\
\hline 19 & 46 & M & 31 & 2.0 & 30 & No \\
\hline 20 & 37 & $\mathrm{~F}$ & 17 & 6.0 & 10 & No \\
\hline 21 & 54 & $\mathrm{~F}$ & 29 & 8.0 & 360 & No \\
\hline Mean \pm SD & $53.1 \pm 9.2$ & $\begin{array}{l}\text { M12 } \\
\text { F9 }\end{array}$ & $29.4 \pm 10.7$ & $4.07 \pm 1.85$ & $38.1 \pm 77.7$ & $\begin{array}{l}16 \text { nonsmokers } \\
5 \text { current smokers }\end{array}$ \\
\hline
\end{tabular}

only 21 out of the 25 farmers. The study thus consisted of 21 farmers with previously diagnosed FLD, who had stayed on their farms (12 men and 9 women), aged from 37 to 76 years (mean 53.1 \pm SD 9.2). Information on farming conditions, including age, sex, years on the farm, working hours per day in barns, hay-handling time per day, and smoking habits, is shown in Table 1.

\section{Methods}

\section{Selection of the dust mask}

A sample of moldy hay from the working environment was obtained locally and an inspirable fraction of the dust was collected using an Andersen sampler. The dust particles sampled had a median diameter of $9.5 \mu$. An oro-nasal ("half-mask") dust mask (Shigematsu DR-74, Tokyo) was selected, since this mask can filter $99.9 \%$ of particles greater than $1.0 \mu$ in diameter.

\section{Application for farmers with FLD}

(1) All 21 farmers in this study were supplied with this mask (DR-74) and recommended to wear it during farming, or at least during hay handling. Each patient agreed to wear the mask. (2) Previous episodes and episodes for the 2 years while wearing the DR-74 were examined by questionnaire, personal records obtained every year during the field survey for FLD, and 7 medical examinations. (3) Practicality of the mask was examined by questionnaire.

\section{Environmental provocation test}

For further evaluation, an environmental provocation test was done with the full agreement of all of the subjects. On the first day, the subjects were examined by interview, chest auscultation, chest roentgenograms, and respiratory functions [forced vital capacity (FVC), forced expiratory volume in one second $\left(\mathrm{FEV}_{1}\right)$, and diffusing capacity $\left.\left(\mathrm{D}_{\mathrm{L}} \mathrm{co}, \mathrm{D}_{\mathrm{L}} / \mathrm{V}_{\mathrm{A}}\right)\right]$. On the second day, the same examinations were done 4 to 8 hours after routine hay handling work without the mask. Paired $\mathrm{t}$-test was performed and a $\mathrm{p}$ value less than 0.01 was regarded as significant.

\section{Results}

\section{1) Practicality of the dust mask (DR-74) (Table 2)}

During the 2-year period from 1985 to 1986,17 farmers $(81 \%)$ wore the mask while working. Four farmers discontinued use of the mask, because they felt uncomfortable with it and had no symptoms of FLD without it. Eight farmers complained of feeling hot or breathless, but were able to tolerate the mask while working for 2 years.

\section{2) Examination of acute episodes of FLD (Table 3)}

While the farmers had previous episodes 0 to 15 times during the 5-year period from 1980 to 1984, seven physical examinations from 1985 to 1986 revealed that no new severe episodes had occurred. Eighteen farmers 
KuSAKA et al

Table 2. Practical Use of Dust Mask (DR-74)

\begin{tabular}{rlll}
\hline Case & Conditions of use & Subject's impression & The point at issue \\
\hline 1 & Stopped using & No need to use & Big, uncomfortable \\
2 & Stopped using & No need to use & Hot \\
3 & During barn work & Good & None \\
4 & During hay handling & Good & None \\
5 & During hay handling & Good & None \\
6 & During barn work & Good & None \\
7 & During hay handling & Good & Hot \\
8 & During hay handling & Good & Hot \\
9 & Stopped using & No need to use & Big, uncomfortable \\
10 & During barn work & Good & None \\
11 & During hay handling & Tolerated & Breathlessness \\
12 & Stopped using & No need to use & Uncomfortable \\
13 & During hay handling & Good & None \\
14 & During hay handling & Good & None \\
15 & During hay handling & Good & None \\
16 & During barn work & Good & Hot \\
17 & During barn work & Tolerated & Hot, breathlessness \\
18 & During hay handling & Good & Hot \\
19 & During barn work & Excellent & None \\
20 & During barn work & Good & Hot \\
21 & During barn work & Good & Hot \\
\hline
\end{tabular}

Table 3. Acute Episodes of FLD

\begin{tabular}{|c|c|c|c|c|}
\hline \multirow[b]{2}{*}{ Case } & \multirow[b]{2}{*}{$\begin{array}{l}\text { Year of the first } \\
\text { attack of FLD }\end{array}$} & \multicolumn{3}{|c|}{ Recurrences } \\
\hline & & $1974-’ 79$ & '80-'84 & $' 85-' 86$ \\
\hline 1 & 1982 & 0 & 1 & 0 \\
\hline 2 & 1974 & $1^{*}$ & 0 & 0 \\
\hline 3 & 1977 & 6 & $12^{*}$ & 0 \\
\hline 4 & 1982 & 0 & 1 & 0 \\
\hline 5 & 1981 & 0 & $1^{*}$ & 0 \\
\hline 6 & 1982 & 0 & $2^{*}$ & 0 \\
\hline 7 & 1982 & 0 & $1^{*}$ & 0 \\
\hline 8 & 1980 & 0 & $1^{*}$ & 0 \\
\hline 9 & 1982 & 0 & $1^{*}$ & 0 \\
\hline 10 & 1982 & 0 & 7 & 1 \\
\hline 11 & 1975 & 4 & 0 & 0 \\
\hline 12 & 1979 & 1 & 0 & 0 \\
\hline 13 & 1984 & 0 & 2 & 0 \\
\hline 14 & 1980 & 0 & 1 & 0 \\
\hline 15 & 1982 & 0 & $1^{*}$ & 0 \\
\hline 16 & 1980 & 0 & $1^{*}$ & 0 \\
\hline 17 & 1979 & 1 & 1 & 2 \\
\hline 18 & 1981 & 0 & $1^{*}$ & 0 \\
\hline 19 & 1980 & 0 & $15^{*}$ & 0 \\
\hline 20 & 1981 & 0 & $4^{*}$ & 0 \\
\hline 21 & 1983 & 0 & $6^{*}$ & $2^{*}$ \\
\hline
\end{tabular}

* Hospitalization and/or steriod treatment was done

did not experience any acute episodes after 1985 (Table 3 ). Three farmers (cases 3, 10, and 19) who had symptoms were able to work without difficulty, even in situations which had formerly made them acutely ill. Three farmers (cases 10,17, and 21) experienced episodes several times even after they started wearing the mask while working.

Most farmers with a past history of FLD had normal or subnormal values for respiratory function. The mean and standard deviation (SD) for FVC, $\mathrm{FEV}_{1}$, and $\mathrm{D}_{\mathrm{L}}$ co were $3.43 \pm 0.911,2.64 \pm 0.771$, and $5.06 \pm 1.351 /$ torr/ min, respectively. One farmer (case 10) had volumes less than $80 \%$ of the predicted values. Three farmers (cases 6,10 and 21 ) had less than $75 \%$ of the predicted $D_{L}$ co values. Challenge exposures were carried out in the farmers' cowsheds for 40-270 minutes (mean $161 \pm$ SD 59) (Table 4). In the environmental provocation test, two farmers complained of chills or fever. Chest physical findings and chest roentgenograms showed no significant changes. When the percent or lung volume change from the control value was over $10 \%$ or 0.21 , respectively, this was thought to be a significant change (7). Decreases in FVC values were seen in 3 cases (cases 1, 4, and 5), $\mathrm{FEV}_{1}$ in 5 cases (cases $4,5,8,14$, and 19 ), and $\mathrm{D}_{\mathrm{L}}$ co in 3 cases (cases 3, 4, and 7) (Table 4). In overall analysis, statistically significant reductions in FVC (mean 3.43 to $3.351, \mathrm{p}<0.01$ ), $\mathrm{D}_{\mathrm{L}}$ co (mean 19.6 to $18.2 \mathrm{ml} /$ torr $/ \mathrm{min}, \mathrm{p}<0.01)$ and $\mathrm{D}_{\mathrm{L}} / \mathrm{V}_{\mathrm{A}}$ (mean 5.1 to $4.8\left(\times 10^{-3}\right)$ $1 /$ torr $/$ min, $p<0.01)$ were observed several hours after exposure (Table 5).

\section{Discussion}

The major findings in this study were: 1) The dust mask (DR-74) was practically used, 2) with the mask, no new severe episodes of FLD developed in 20 of the 21 farmers with FLD studied over a 2-year period, and after that period, the incidence of acute episodes of FLD was markedly decreased, 3) when the farmers took 
Protective Value of Masks against FLD

Table 4. Environmental Provocation Test

\begin{tabular}{|c|c|c|c|c|}
\hline \multirow[b]{2}{*}{ Case } & \multicolumn{2}{|c|}{ Provocation time } & \multicolumn{2}{|c|}{ After exposure } \\
\hline & $\begin{array}{l}\text { Barn-working } \\
\text { time (min) }\end{array}$ & $\begin{array}{l}\text { Hay-handling } \\
\text { time (min) }\end{array}$ & Symptoms & $\begin{array}{c}\text { Positive respiratory } \\
\text { functional parameters }\end{array}$ \\
\hline 1 & 150 & 50 & & FVC \\
\hline 2 & 40 & 10 & & \\
\hline 3 & 180 & 10 & & $\mathrm{D}_{\mathrm{L}} \operatorname{co}, \mathrm{D}_{\mathrm{L}} / \mathrm{V}_{\mathrm{A}}$ \\
\hline 4 & 150 & 90 & & FVC, $\mathrm{FEV}_{1}, \mathrm{D}_{\mathrm{L}}$ co \\
\hline 5 & 210 & 60 & & FVC, FEV $_{1}$ \\
\hline 6 & 180 & 5 & & $\mathrm{D}_{\mathrm{L}} / \mathrm{V}_{\mathrm{A}}$ \\
\hline 7 & 90 & 0 & & $\mathrm{D}_{\mathrm{L}}, \mathrm{D}_{\mathrm{L}} / \mathrm{VA}$ \\
\hline 8 & 120 & 60 & & $\mathrm{FEV}_{1}$ \\
\hline 9 & 180 & 0 & & \\
\hline 10 & 90 & 30 & Chill & \\
\hline 11 & 160 & 30 & & $\mathrm{D}_{\mathrm{L}} / \mathrm{V}_{\mathrm{A}}$ \\
\hline 12 & 220 & 10 & & \\
\hline 13 & 150 & 30 & & $\mathrm{D}_{\mathrm{L}} / \mathrm{VA}$ \\
\hline 14 & 170 & 55 & & $\mathrm{FEV}_{1}$ \\
\hline 15 & 240 & 15 & & \\
\hline 16 & 150 & 30 & & \\
\hline 17 & 90 & 20 & & \\
\hline 18 & 270 & 90 & & \\
\hline 19 & 240 & 60 & Fever & $\mathrm{FEV}_{1}$ \\
\hline 20 & 210 & 40 & & \\
\hline 21 & 90 & 60 & & \\
\hline Mean $\pm \mathrm{SD}$ & $161 \pm 59$ & $36 \pm 28$ & & \\
\hline
\end{tabular}

Table 5. Changes in Respiratory Functional Parameters by Environmental Provocation Tests

\begin{tabular}{lccc}
\hline & Before exposure & After exposure & Paired t test \\
\hline FVC $(1)$ & $3.43 \pm 0.91$ & $3.35 \pm 0.88$ & $\mathrm{p}<0.01$ \\
$\% \mathrm{FVC}(\%)$ & $112 \pm 20$ & $109 \pm 19$ & $\mathrm{p}<0.01$ \\
$\mathrm{FEV}_{1}(\mathrm{l})$ & $2.64 \pm 0.77$ & $2.56 \pm 0.70$ & $\mathrm{p}<0.05$ \\
$\mathrm{FEV}_{1} / \mathrm{FVC}(\%)$ & $77 \pm 6$ & $76 \pm 6$ & $\mathrm{NS}$ \\
$\mathrm{D}_{\mathrm{L}}$ co $(\mathrm{ml} /$ torr/min $)$ & $19.6 \pm 6.3$ & $18.2 \pm 5.4$ & $\mathrm{p}<0.01$ \\
$\% \mathrm{D}_{\mathrm{L}}$ co $(\%)$ & $105 \pm 28$ & $98 \pm 22$ & $\mathrm{p}<0.01$ \\
$\mathrm{D}_{\mathrm{L}} / \mathrm{V}_{\mathrm{A}}(1 /$ torr $/ \mathrm{min})$ & $5.1 \pm 1.3$ & $4.8 \pm 1.2$ & $\mathrm{p}<0.01$ \\
$\% \mathrm{D}_{\mathrm{L}} / \mathrm{V}_{\mathrm{A}}(\%)$ & $103 \pm 26$ & $97 \pm 25$ & $\mathrm{p}<0.01$ \\
\hline
\end{tabular}

NS: not significant (mean $\pm \mathrm{SD})$. Values are mean $\pm \mathrm{SD}$

off the dust masks while farming for an environmental provocation test, statistically significant reductions in FVC, $D_{L} c o, D_{L} / V_{A}$ were observed several hours after exposure. These findings suggest that the dust mask is used practically and is effective in decreasing the incidence of acute episodes of FLD during routine dairy farming work.

For highly sensitive patients with FLD, reexposure to minute amounts of the offending antigens may suffice to cause symptoms to recur. Continuous reexposure or numerous subacute episodes of hypersensitivity pneumonitis can lead to pulmonary fibrosis. Therefore, previously it was recommended that most, if not all, patients with FLD should move away from the farm environment (1-4). It is questionable whether all farmers with a past history of FLD should stop farming. Some studies $(8,9)$ have shown that continued contact after an acute attack of FLD may not necessarily lead to progressive respiratory deterioration. The prognosis appears to be good in such patients if acute febrile episodes do not recur. In a follow-up study of 92 subjects with the acute form of FLD, Braun et al (9) showed that 64 subjects $(70 \%)$ were still living on farms after a mean duration of 14.8 years from the first episode. Moreover, they reported that there had been no significant relationship between continued farming or the length of disease and lung function, and that symptomatic recurrences might be the most important factor in de- 
termining the danger of progressive disease. In 1985, Cormier and Bélanger (10) reported that after an episode of acute FLD, most farmers did not progress to disabling pulmonary fibrosis even if they stayed on the farm. They stated that their current policy was to recommend continued farming, take all possible preventive measures, have regular evaluations of pulmonary function, and consult a physician at the slightest suspicion of recurrence.

There are two ways of avoiding the inhalation of organic dusts in patients with FLD without changing occupation: 1) Appropriate ventilation facilities at working areas and mechanization of the feeding process, and 2) use of masks with filters capable of removing the antigenic dust. A dust mask may diminish or prevent recurrent attacks of the disease. However, the practical use and effectiveness of dust masks as a preventive measure has not been fully studied.

In a survey of FLD in Devon in England, Smyth et al (11) reported in 1975 that many farmers had not used efficient masks with a large disposable filter, because they were more cumbersome and less comfortable while working than the inefficient masks with gauze filters. Therefore, it was necessary to study the practicality of a simple dust mask (DR-74) as well as its effectiveness as a preventive measure against FLD during routine dairy farming work. In our survey, dust masks were tolerable for most farmers $(81 \%)$ with FLD even for a long period. The 4 farmers who discontinued use of the mask had experienced only a small episodes one time or had not experienced any acute episodes of FLD for a considerable time, so that they did not use a mask or used a simple gauze mask.

The efficiency of dust masks in preventing chronic disease after continued long-term exposure has not been tested, but limited information indicates that some dust masks can protect farmers from acute reactions after single exposures to organic dust. Gourley and Braidwood (12) reported in 1971 the results of a provocative trial carried out on a sensitized farmer with the exposure of forking a bale of his own moldy hay for one hour. They found that a dust mask using negative pressure filtration (Baxter Pneu-Seal respirator) was highly effective and acceptable to the patient, and that it removed $98 \%$ of 0.8 $\mu$-diameter particles. The masks which we used are capable of filtering out $99.9 \%$ of particulate matter greater than $1.0 \mu$ in diameter, thus outperforming the dust mask Gourley and Braidwood used.

Hendrick et al (13) examined the efficiency of negative pressure filtration respirators in preventing acute reactions by doing identical paired inhalation provocation tests using a natural method of antigen exposure. They reported in 1981 that the industrial dust mask used offered substantial protection against single exposure to environmental dusts in six patients with bird-fancier's lung, pigeon breeder's lung, or mushroom worker's lung. In 1989 Müller-Wening and Repp (14) investigated in the same way the protective value of a breathing mask in six patients with FLD using the double-inhalation challenge test. They concluded that pulmonary and systemic alterations were significantly reduced but not completely prevented by the application of the particlefiltering half mask. Moreover, they reported that when using the mask, all subjects were free of symptoms, and that the mask had a protective effect against acute attack. However, these two studies did not answer the question of whether the development of a chronic state might be prevented by use of a mask.

The present follow-up study of 21 farmers with FLD during a 2-year period may answer this question. No new severe episodes of FLD developed in 20 of the 21 farmers with FLD over the 2-year study period, and the incidence of acute episodes of FLD was markedly decreased. No alterations were shown on chest X-rays and pulmonary function tests for 2 years.

The environmental provocation test is carried out by reexposing the patients to the suspected work environment. There is less danger in this type of provocation than in laboratory inhalation provocation tests. A typical acute attack with fever, rales, leukocytosis, and pulmonary function abnormalities occurring 4 to 8 hours after exposure may be produced with the suspected antigen. However, in the environmental provocation test the symptomatic and physiologic abnormalities are produced less clearly than in laboratory tests. Moreover, results of both types of provocation tests must be interpreted critically, because bacterial endotoxin and other irritants in the dust introduce febrile reactions in certain normal individuals (15). We did not examine mycotoxins.

A restrictive type of ventilatory impairment is a common finding in acute FLD. In this study we used the criterion that Hargreave and Pepys proposed (7), although there has not yet been an established criterion for provocation tests. A fall in $\mathrm{VC}$ and $\mathrm{FEV}_{1}$ of $10 \%$ or $0.2 \mathrm{l}$ or more compared with the control day and occurring within several hours of provocation testing was regarded as a significant reaction. Reduced lung diffusing capacity $\left(D_{L} \mathrm{co}\right)$ is almost the rule at the acute stage of FLD and appears to be the most sensitive indicator of lung function failure (16). Airway obstruction has been reported as a sign of chronic FLD when combined with a defect in gas transfer, and with or without restrictive ventilatory impairment $(3,8)$.

In the present study, marked alterations of pulmonary functions were not seen. However, whether the concentration of the antigen is adequate to cause a positive response is always arguable. In this study also, there was a possibility that some farmers avoided inhaling antigens consciously or subconsciously. In our investigation, decreases of $\mathrm{FVC}$ and/or $\mathrm{FEV}_{1}$ were seen in 6 farmers, and 6 farmers showed a fall in $D_{L}$ co or $D_{L} / V_{A}$ of $10 \%$ or more. Eleven of the 21 farmers $(52 \%)$ showed some alterations of respiratory functions after exposure. As a 


\section{Protective Value of Masks against FLD}

whole, significant falls in $\mathrm{FVC}, \mathrm{D}_{\mathrm{L}} \mathrm{co}$, and $\mathrm{D}_{\mathrm{L}} / \mathrm{V}_{\mathrm{A}}$ were seen with a p-value less than 0.01 by the paired t-test. These pulmonary responses after taking off the dust mask may conversely suggest the effectiveness of the mask as a preventive measure against FLD.

It is concluded that this type of dust mask was used practically during routine dairy farming work and was effective as a protection against FLD over 2-year period.

\section{References}

1) Dickie HA, Rankin J. Farmer's lung: An acute granulomatous interstitial pneumonitis occurring in agricultural workers. JAMA 167: 1069, 1958.

2) Emanuel DA, Wenzel FJ, Bowerman CF, Lawton BR. Farmer's lung: Clinical, pathologic, and immunologic study of twenty-four patients. Am J Med 37: 392, 1964.

3) Hapke EJ, Seal RME, Thomas GO, Hayes M, Meek JC. Farmer's lung: A clinical, radiographic, functional and serologic correlation of acute and chronic stages. Thorax 23: 451, 1968.

4) Schuyler M, Salvaggio JE. Hypersensitivity pneumonitis. Seminars in Respiratory Medicine 5: 246, 1984.

5) Homma Y, Terai T, Matsuzaki M. Incidence of serum-precipitating antibodies to farmer's lung antigens in Hokkaido. Respiration 49: 300, 1986.

6) Kusaka H, Homma Y, Ogasawara H, et al. Five-year follow-up of Micropolyspora faeni antibody in smoking and nonsmoking farmers. Am Rev Respir Dis 140: 695, 1989.

7) Hargreave FE, Pepys J. Allergic respiratory reactions in bird fanciers provoked by allergen inhalation provocation tests. J Allergy Clin Immunol 50: 157, 1972.

8) Barbee RA, Callies Q, Dickie HA, Rankin J. The long-term prognosis in farmer's lung. Am Rev Respir Dis 97: 223, 1968.

9) Braun SR, doPico GA, Tsiatis A, Horvath E, Dickie HA, Rankin J. Farmer's lung disease: long-term clinical and physiologic outcome. Am Rev Respir Dis 119: 185, 1979.

10) Cormier Y, Bélanger J. Long-term physiologic outcome after acute farmer's lung. Chest 87(6): 796, 1985.

11) Smyth JT, Adkins GE, Lloyd M, Moore B, McWhite E. Farmer's lung in Devon. Thorax 30: 197, 1975.

12) Gourley CA, Braidwood GD. The use of dust respirators in the prevention of recurrence of farmer's lung. Trans Soc Med 21: 93 , 1971.

13) Hendrick DJ, Marshall R, Vaox JA, Krall JM. Protective value of dust respirators in extrinsic allergic alveolitis: clinical assessment using inhalation provocation tests. Thorax 36: 917, 1981.

14) Müller-Wening $D$, Repp $H$. Investigation on the protective value of breathing masks in farmer's lung using an inhalation provocation test. Chest 95: 100, 1989.

15) Warren P, Cherniack RM, Tse KS. Hypersensitivity reactions to grain dust. J Allergy Clin Immunol 53: 139, 1974.

16) Matsuzaki $M$, Ogasawara $H$, Munakata $M$, et al. Significances of diffusing capacity of the lung (DLCO) for the early detection and assessment of remission in farmer's lung (FL). Japanese Journal of Thoracic Diseases 23(8): 859, 1985 (in Japanese with English abstract). 